\title{
Boosting Hypericin and Herb Yield of Hypericum triquetrifolium L. by Leaf Enlargement
}

\author{
Moh`d Al Rifaee, Fadel Ismail, Moa'th Al Gharaibeh \\ National Center for Agricultural Research and Extension (NCARE), Biodiversity Department, P.O.Box 639 Amman Baqa`19381, Jordan
}

Correspondence Author: Moh`d Al Rifaee, National Center for Agricultural Research and Extension (NCARE), Biodiversity Department, P.0.Box 639 Amman Baqa`19381, Jordan.

E-mail: m.rifaee@ncare.gov.jo

Received date: 22 December 2017, Accepted date: 22 January 2018, Online date: 5 February 2018

Copyright: (C) 2018 Moh`d Al Rifaee, et al. This is an open-access article distributed under the terms of the Creative Commons Attribution License, which permits unrestricted use, distribution, and reproduction in any medium, provided the original author and source are credited.

\begin{abstract}
Hypericum triquetrifolium is a source for the active metabolite hypericin that used as antitumor, antiviral and antidepressant. The aim of this study was to enlarge the small-sized leaves of the plant to maximize the hypericin and herb yield. Seeds were collected from two wild populations in Jordan (Ramtha and Amman) and soaked in varied colchicine concentrations for different periods. Seedling survival averaged $22.4 \%$, and the lowest survival (4.4\%) recorded when the colchicine treatment $0.3 \%$ was used. For two growing seasons (2014 and 2015) plants were morphologically described in the filed then harvested. Colchicine randomly accelerated or reduced hypericin content and growth. Treated plants produced $34.4 \%$ higher hypericin than untreated plants and the highest hypericin content $(0.379 \%)$ extracted from a plant treated by $0.3 \%$ colchicine for 30 hours. Plants varied in dry weight and produced stunted ( 2 to $4 \mathrm{~g}$ ) to a huge plants (more than $50 \mathrm{~g}$ ) comparing to untreated plants (average $22 \mathrm{~g}$ ). The highest hypericin producing plant harvested 69\% more dry weight over the treatment's mean and totaled $10.2 \mathrm{mg}$ hypericin plant ${ }^{-1}$. The highest dry weight $(86.6 \mathrm{~g})$ producing plant harvested $229.8 \%$ more dry weight over the treatment's mean and totaled 13.7 mg hypericin plant $^{-1}$. As hypericin content increased, greatest number of the hypericin black nodules on leaves was counted; this character can be used for plant selection in the wild populations. Considerably, treated plants developed varied leaf sizes (9 to 64 leaves in 6.25 inch ${ }^{2}$ ) and varied leaf shapes (ovoid, linear, elliptic and ovate). Genetically, treated plants were separated in different groups, while untreated plants grouped solely. Certain treated plants were grouped uniquely including the plant with the lowest hypericin content and the plant with the highest dry weight and total hypericin production. These results are reflecting the genetic modifications and diversity within the new developed plants. The developed plants with higher hypericin and herb yield will be increased by tissue culture for proper homogeneity and field establishments and their seeds and generated progenies will be evaluated.
\end{abstract}

Key words: AFLP, colchicine, dark nodules, dry weight, HPLC

\section{INTRODUATION}

The genus Hypericum is diverse, encompassing about 500 species [1, 2] and distributed throughout nearly all continents [3]. It is of great medicinal importance and commercial for the phytochemical constituents $[4,5]$. Among this genus, H. perforatum is widely used in official medicine and a well-known traditional medicinal plant that has been used for centuries for the treatment of several diseases, such as skin lesions, eczema, burns and microbial, inflammatory, and psychological disorders [6]. H. triquetrifolium Turra is another species widespread in warm-temperate areas throughout the world and well represented in the Mediterranean and in the Near East. Activities of H. triquetrifolium sign out the great potential of this species as a promising medicinal plant [7]. It has traditionally been used in the treatment of burns and gastrointestinal disease [8], anti-inflammatory [9], antibacterial [10], antifungal [11], antioxidant, and cytotoxic [12] and its extracts are a potential source of natural antioxidants [13]. Also, H. triquetrifolium is a source of a variety of biologically active compounds including, chlorogenic acid, hyperoside, apigenin-7-O-glucoside, kaempferol, quercetin and amentofl avone accumulations, rutin and quercitrin [14]. Although $\mathrm{H}$. triquetrifolium is an important source for hypericin [15] that contribute to antidepressant activity [16], which is the most common health condition that affects $80 \%$ of humans during part of their life [17]. In a study large numbers of Hypericum species were tested and hypericin was not detected in more than 60 species [18]. Also, H. triquetrifolium identified leaf essential oils are n-nonane $(15 \%), \beta$-pinene $(4 \%)$, $\alpha$-pinene $(10 \%)$, myrcene $(5 \%), \beta$-caryophyllene $(11 \%)$, germacrene-D (13\%), sabinene (3\%) and caryophyllene oxide (12\%) [19].

The wild populations of $\mathrm{H}$. triquetrifolium in Jordan contains varied hypericin from $0.03 \%$ to $0.14 \%$ extracted from the collective plant parts; leaf, stem and flower, and when the plant introduced to cultivation the best hypericin content was $0.16 \%$ and the total dry herb yield was $9.3 \mathrm{t}$ ha- 1 [20]. Also, the plant leaves contained the highest hypericin content $(0.4 \%)$ whereas stems and flowers contain only traces. The leaf of this plant is a small in size (3-10 mm in length and 2-4 $\mathrm{mm}$ in width) and accounted for $34 \%$ of the total dry plant. This research hypothesized the enlargement of $\mathrm{H}$. triquetrifolium leaves using the antimitotic colchicine. The optimum materials, concentration and soaking time were examined to identify the effective treatment(s) to develop cultivated varieties with high hypericin content and herb yield.

Methodology:

Seed collection and treatments: 
H. triquetrifolium seeds collected in the summer (2013) from two wild populations in Jordan; Ramtha (north, $32^{\circ} 27^{\prime} 58.7^{\prime \prime} \mathrm{N}$ latitude, $35^{\circ} 57^{\prime} 51^{\prime \prime} \mathrm{E}$ longitude, $614 \mathrm{~m}$ altitude, and $214 \mathrm{ml}$ rainfall long-term average) and Amman (center, $31^{\circ} 48^{\prime} 16.9^{\prime \prime} \mathrm{N}$ latitude, $35^{\circ} 54^{\prime} 51.1^{\prime \prime} \mathrm{E}$ longitude, $783 \mathrm{~m}$ altitude, and 176 $\mathrm{ml}$ rainfall long-term average). The two populations reported hypericin content greater than $0.1 \%$ collectively in leaf, stem and floral parts [20]. Collected seeds were cleaned from fruit capsule residues, scarified three times with desalted sand to remove the gummy layer surrounding the seeds, and washed several times with water, and then used for polypoid induction the next day.

In February 2014, seeds from the two populations were treated by the antimitotic colchicines (Santa Cruz Biotech., USA). Seeds were imbibed in water for $24 \mathrm{~h}$ then placed on filter papers soaked with 5 different colchicine solutions $(0.05,0.1,0.2,0.3$ and $0.4 \%)$ and for 3 different treatment`s periods $(18,24$ and $30 \mathrm{~h})$, all of the treatments were replicated 3 times.

\section{Cultivation and morphology:}

Treated seeds were directly germinated in polystyrene trays $\left(4 \times 4 \mathrm{~cm}\right.$ cells) containing peatmoss and placed in a greenhouse (minimum temperature, $\left.26^{\circ} \mathrm{C}\right)$, each treatment was replicated 30 times. Germinated seedlings were maintained in moist conditions for 2 months before thinning to one per cell (5-8 $\mathrm{cm}$ tall). Total number of sown cells was 900 \{5 colchicine (\%) x 3 treatment periods (h) x 30 replications x $2 \mathrm{H}$. triquetrifolium wild populations $\}$. Percentages of seed germination and seedlings survival were determined on 20 and 45 days after seed sowing, respectively. On late June, seedling were transferred to the field at $\mathrm{Al}$ Baq a Research Station (center, $32^{\circ} 04^{\prime} 46.56^{\prime \prime} \mathrm{N}$ latitude, $35^{\circ} 50^{\prime} 42.72^{\prime \prime} \mathrm{E}$ longitude, $800 \mathrm{~m}$ altitude, and $325 \mathrm{ml}$ rainfall long-term average). The field location has a characteristic Mediterranean climate and is classified as a semi-arid zone. Soil texture of the field was clay (pH 7.8, EC $0.56 \mathrm{dS} / \mathrm{m}, \mathrm{CaCO} 34 \%$, organic matter $0.5 \%, \mathrm{~N} 0.06 \%, \mathrm{P} 3.1 \mathrm{ppm}, \mathrm{K} 126 \mathrm{ppm}$ ). Soil was prepared using a disc plow followed by duck-foot plow. The distance between rows was $1 \mathrm{~m}$ and the distance between the plants within the rows was $40 \mathrm{~cm}$ and the plants beds were holes $(50 \times 50 \times 30 \mathrm{~cm})$. Bird nets was used to shade the seedling at the early stage of transplanting then removed, and irrigation was in the frequent first year using a drip irrigation system. Plants survival in the field was recorded after three weeks and for comparisons, data were collected for three untreated control plants from Ramtha and Amman wild populations and their standard deviations from means were calculated.

Morphological measurements were collected from each plant during the flowering period for two growing seasons (2014 and 2015) included: plant height, leaf size (number of random leaves in 6.25 inch 2), dark nodules (number from random leaves using lens), and nodules distribution in the leaf, leaf shape, and leaf arrangement on the stems. At the full bloom stage, plants were harvested $(5 \mathrm{~cm}$ above soil surface) on mid-August. After harvesting, all plants were dried in the shade (to retain color and preserve quality) at $30 \pm 5^{\circ} \mathrm{C}$ for 5 days and their dry weights were recorded. Leaf ration were determined by weighing separated dry parts from random branches.

\section{Genetic study:}

Amplified fragment length polymorphisms (AFLP) finger prints were used to compare the genetic similarity between H. triquetrifolium untreated controls and their treated derivatives. The top six hypericin producing treated plants and the lowest producing plant from Ramtha and Amman populations as well as a 3 untreated plant from each population were used to generate the finger prints. Four to five young and healthy leaves form regenerated plants were collected in the spring of 2015 and bulked together for DNA isolation. DNA was extracted using the isolation kit (NucleoSpinß-Germany). Samples DNA were quantified through comparing the size and intensity of each sample band with 100 bp DNA mass ladder (Promega; Madison, USA) using agarose gel (0.7\%). AFLP data were generated using six different selective primer combinations (table 1) [21].

AFLP amplified products were scored as present (1) or absent (0) of DNA bands for each sample by visual inspection of the gel photograph. The presence or absence of an amplified fragment was treated as an independent character without considering of the qualitative aspects of the results, i.e. band intensity. Pair-wise comparisons of populations, based on unique and shared polymorphic products, were used to generate Nei genetic distance [22] then the genetic distance coefficients were used to construct the dendrogram, using NTSYSpc (version 2.1) software package [23].

Table 1: AFLP performed and selective primers.

\begin{tabular}{|l|l|}
\hline Name of Primer/Adapter & Sequence (5'-3') \\
\hline Ligation & \multicolumn{2}{l|}{ RI adapter } & $\begin{array}{l}\text { CTCGTAGACTGCGTACC } \\
\text { AATTGGTACGCAGTC }\end{array}$ \\
\hline Mse I adapter & $\begin{array}{l}\text { GACGATGAGTCCTGAG } \\
\text { TACTCAGGACTCAT }\end{array}$ \\
\hline Eco RI primers & \\
\hline Pre amplification & GACTGCGTACCAATTCA \\
\hline E-A & \\
\hline Selective amplification primers & GACTGCGTACCAATTCAAC \\
\hline E-AAC labeled IRDye 700 & GACTGCGTACCAATTCACT \\
\hline E-ACT labeled IRDye 800 & \\
\hline Mse I primers & \\
\hline Pre amplification & GATGAGTCCTGAGTAAC \\
\hline M-C & \\
\hline Selective amplification primers & GATGAGTCCTGAGTAACAA \\
\hline M-CAA & GATGAGTCCTGAGTAACAC \\
\hline M-CAC & GATGAGTCCTGAGTAACAT \\
\hline M-CAT & GATGAGTCCTGAGTAACAG \\
\hline M-CAG & GATGAGTCCTGAGTAACTG \\
\hline M-CTG & GATGAGTCCTGAGTAACTC \\
\hline M-CTC & \\
\hline
\end{tabular}

\section{Hypericin analysis:}

Dry plants were analyzed for hypericin content (3 replications) by high performance liquid chromatography (HPLC) following the analytical protocol reported for Hypericum triquetrifolium [15]. The hypericin percentage was calculated against a reference standard (Santa Cruz Biotech.-USA) developed from stock solution of $1000 \mu \mathrm{g} \mathrm{mL}-1$ hypericin prepared by mixing and sonicating $1 \mathrm{mg}$ hypericin standard in $1 \mathrm{~mL}$ HPLC-grade methanol. The stock solution was then used to prepare five reference samples: $25,50,75,100$, and $125 \mu \mathrm{g} \mathrm{mL}-1$. The HPLC separation was done using a Shimadzu systems (Japan) unit equipped with a Spherisorb $(\mathrm{C} 18,4.0 \times 125 \mathrm{~mm} 5 \mu \mathrm{m})$ column. The mobile phase was an isocratic mixture of methanol:phosphate buffer:ethyl acet ate in a ratio of (360:117.5:100, v:v:v). The phosphate buffer was prepared by dissolving $0.78 \mathrm{~g}$ of sodium dihydrogen phosphate dihydrate in $500 \mathrm{~mL}$ of deionized water and adjusting to $\mathrm{pH} 2.1$ \pm 0.1 using phosphoric acid. Injection volume was $20 \mu \mathrm{L}$ for $10 \mathrm{~min}$ with flow rate of $1.0 \mathrm{~mL} / \mathrm{min}$, and detection was at $590 \mathrm{~nm}$. A calibration curve for hypericin concentration was constructed using the standards $(\mathrm{r} 2=0.95)$ and percent hypericin in samples was calculated against the hypericin standards using the equation: Hypericin $(\%)=[\mathrm{mg} \mathrm{mL}-1$ hypericin $\mathrm{x}$ sample volume $(25 \mathrm{~mL}) \mathrm{x}$ dilution $(1) \mathrm{x} 100 \%] /$ [Sample weight $(\mathrm{mg})]$ 


\section{RESULTS AND DISCUSSIONS}

Seed germination after treatments and sowing started in 10 days in the greenhouse, and the total survived seedlings on day 45 was 202 (survival percent 22.4\%); those were 71 and 131 seedlings were from Ramtha and Amman wild populations, respectively (table 2). Seedlings originated from Amman wild population were faster in germination, more survived and tolerant to colchicine treatment than Ramtha population; average seedlings survivals were $29.1 \%$ and $15.8 \%$ for Ramtha and Amman, respectively. Survival influenced by the colchicine treatments, where the highest survival was recorded when $0.1 \%$ colchicine used (average survival 38.3\%), while the lowest survival (lethal) recorded when $0.3 \%$ used with average survival of $4.4 \%$. On the contrary when the $0.4 \%$ colchicine was used average survival was $33 \%$. Time of colchicine treatments has minor effect on the seedling survival with advantage of the shortest period (18 h) averaging $25.7 \%$ seedling survival. In a work on inducing polyploid in Hypericum patulum by soaking seeds and explants in two colchicine concentrations (0.05 and $1 \%)$, seed germination and explants development rate decreased by increasing colchicine percentage and soaking time, and soaking seeds of Hypericum patulum in colchicine did not induced any polyploid, whereas the induction was reported by using explants in invitro conditions under long treatment periods (more than $0.05 \%$ for over 6 hours) [24]. This may be attributed to the low concentrations they used for soaking the seeds in comparison to the ones used in this study.

Leaf enlargements cases of $\mathrm{H}$. triquetrifolium were noticed visually during the seedling stage. Among the 202 survived seedlings in the greenhouse, 150 seedlings were selected according to their leaf size and vegetation vigor, these were transplanted to the field on late June (2014). After three weeks 128 plants were survived under the field conditions while in the 2nd season (2015), 120 plants regrown from this perennial plant; 40 from Ramtha and 80 from Amman populations.

Soaking H. triquetrifolium seeds in colchicine resulted in random effects on plant hypericin content, dry weight yield, morphology (table 3 and 4) and genetic (figure 1). Colchicines have random effects either accelerated or decreased plants hypericin content and growth. The two years old $\mathrm{H}$. triquetrifolium plants produced $41.4 \%$ more hypericin than a one year old plants, so results of two years old plants were adopted to reflect the actual plants potentials. Treated Ramtha plants produced greater hypericin (percent increase 8.4\%) than those of Amman. In comparison to untreated plants, 37.5\% of Ramtha and 31.3\%, Amman treated plants produced higher hypericin over the untreated plants, whereas the majorities were lower than untreated controls $(62.5 \%$ and $68.8 \%$ for Ramtha and Amman, respectively). Results showed that the first ranked with highest hypericin content of $0.379 \%$ developed when Ramtha seeds were soaked in $0.3 \%$ colchicine for 30 hours (percent increase in hypericin was $241.4 \%$ higher than the untreated plants and $97.4 \%$ higher than the best in Amman). Whereas there was a $300 \%$ decrease from untreated plants by the lowest hypericin producing plant (ranked last as 120) form Amman population when soaked in $1 \%$ colchicine for 18 hours.

Colchicine treatments resulted in diverse effects on the plants dry weight within and across the seasons. A two years $\mathrm{H}$. triquetrifolium plants produced bigger plants in comparison to a one year old, but not for all case. Some treated plants become stunt with low dry weight as in the plants ranked for hypericin 2,3 , 6,9 and 11, indicating a depression effect of colchicine on plant growth. Colchicine accelerating effect was obvious in the top hypericin producing plant (rank-1) from Ramtha population which produced $69.1 \%$ more dry herb over the treatment`s mean, with estimated production of 10.23 mg hypericin plant-1. Similarly the highest dry weight producing plant (rank-7) from Amman population produced 229.8\% more dry matter over the treatment's mean, with estimated production of $13.68 \mathrm{mg}$ hypericin plant-1. Also, the acceleration effect of colchicine treatments indicated percent increases in estimated hypericin per plant of $202.6 \%$ and $1227.5 \%$ in plants rank-1 and rank-7 over their untreated controls, respectively.

Treated plants developed varied leaf sizes considerably (from 9 to 64 leaves in 6.25 inch 2). Plants in the second season produced larger leaves than the first. Leaf size was more enlarged in the treated Amman population in comparison to the Ramtha population, mean number were 29.7 and 50.67 plants, respectively. The largest leaves (9 per 6.25 inch 2) were recorded from a plant originated from Ramtha population (rank 116) and produced moderate dry weighty (36.52 g) but it was very low in hypericin content $(0.032 \%)$ and production $(1.17 \mathrm{mg}$ plant-1). The highest dry weight producing plant (rank-7) exceed the top hypericin producing plant (rank-1) in vegetative growth due to its larger leaves (22 in 6.25 inch 2$)$ and taller plants $(45 \mathrm{~cm})$, however both have greater leaf percentages over their untreated plants $(50.8 \%$ and $60 \%$ respectively).

Four leaf shapes were reported in this study; ovoid, linear, elliptic ovate. Colchicine treatments resulted in limited deviations from the original plant characteristics including the development of alternate leaf arrangements for 1 plant (the common is opposite arrangement) and the development of a white and green mosaic leaves, however these plant did not survived for the 2nd growing season.

The active compounds including the hypericin are concentrated in the clusters of specialized cells, so-called 'dark nodules' distributed on the leaves, stems, petals, sepals, stamens and ovules of many Hypericum taxa [2]. Number of dark nodules per leaf was greater in the first season than the second. The highest hypericin producing plant (rank-1) counted the greatest number of nodules per leaf (26) and generally the low hypericin producing plants counted lower numbers, this character can be used to select plants for high hypericin content in large wild populations. Nodules distribution in leaves was mostly even in Amman population while it was varied in Ramtha population (even, not even and scattered).

Table 2: Seed germination (20 d) and seedling survival (45 d) of H. triquetrifolium soaked in varied colchicines.

\begin{tabular}{|c|c|c|c|c|c|}
\hline \multicolumn{2}{|l|}{ Treatment } & \multicolumn{2}{|c|}{ Germination (\%) } & \multicolumn{2}{|c|}{ Seedling survival (\%) } \\
\hline Colchicine (\%) & Soaking time (hrs) & Ramtha & Amman & Ramtha & Amman \\
\hline \multirow{3}{*}{0.05} & 18 & 23.3 & 6.7 & 20.0 & 6.7 \\
\hline & 24 & 30.0 & 6.7 & 30.0 & 6.7 \\
\hline & 30 & 13.3 & 6.7 & 13.3 & 0.0 \\
\hline \multirow{3}{*}{0.1} & 18 & 13.3 & 76.7 & 13.3 & 70.0 \\
\hline & 24 & 10.0 & 63.3 & 10.0 & 56.7 \\
\hline & 30 & 20.0 & 46.7 & 20.0 & 36.7 \\
\hline \multirow{3}{*}{0.2} & 18 & 30.0 & 43.3 & 13.3 & 43.3 \\
\hline & 24 & 30.0 & 43.3 & 13.3 & 40.0 \\
\hline & 30 & 30.0 & 46.7 & 23.3 & 43.3 \\
\hline \multirow{3}{*}{0.3} & 18 & 6.7 & 6.7 & 6.7 & 6.7 \\
\hline & 24 & 6.7 & 0.0 & 6.7 & 0.0 \\
\hline & 30 & 20.0 & 6.7 & 13.3 & 6.7 \\
\hline \multirow{3}{*}{0.4} & 18 & 36.7 & 46.7 & 23.3 & 33.3 \\
\hline & 24 & 10.0 & 70.0 & 10.0 & 53.3 \\
\hline & 30 & 30.0 & 43.3 & 20.0 & 33.3 \\
\hline
\end{tabular}

Ramtha and Amman; H. triquetrifolium wild populations. 
Citation: Moh`d Al Rifaee, Fadel Ismail, Moa'th Al Gharaibeh, 2018. Boosting Hypericin and Herb Yield of Hypericum triquetrifolium L. by Leaf Enlargement. Advances in Environmental Biology., 12(1): 11-15.

Table 3: Hypericin, dry weight and leaf size of $H$. triquetrifolium form Ramtha and Amman populations.

\begin{tabular}{|c|c|c|c|c|c|c|c|}
\hline \multirow[b]{2}{*}{ Treatment } & \multicolumn{2}{|c|}{$\begin{array}{l}\text { Hypericin content } \\
(\% \mathrm{w} / \mathrm{w})\end{array}$} & \multirow{2}{*}{$\begin{array}{l}\text { Rank } \\
\text { Hypericin }\end{array}$} & \multicolumn{2}{|c|}{$\begin{array}{l}\text { Plant dry weight } \\
\text { (g) }\end{array}$} & \multicolumn{2}{|c|}{$\begin{array}{l}\text { Leaf size } \\
\text { (leaf no. in } 6.25 \text { inch }^{2} \text { ) }\end{array}$} \\
\hline & $1^{\text {st }}$ Season & $2^{\text {nd }}$ Season & & $1^{\text {st }}$ Season & $2^{\text {nd }}$ Season & $1^{\text {st }}$ Season & $2^{\text {nd }}$ Season \\
\hline \multicolumn{8}{|l|}{ Colchicine (\% / hrs) } \\
\hline \multicolumn{8}{|l|}{ Ramtha } \\
\hline $0.3 / 30$ & $0.098( \pm 0.001)$ & $0.379( \pm 0.125)$ & 1 & 18.6 & 26.9 & 28 & 41 \\
\hline $0.2 / 30$ & $0.129( \pm 0.002)$ & $0.325( \pm 0.108)$ & 2 & 19.1 & 4.9 & 39 & Stunt \\
\hline $0.1 / 30$ & $0.257( \pm 0.001)$ & $0.197( \pm 0.092)$ & 3 & 12.7 & 1.6 & 36 & Stunt \\
\hline $0.2 / 24$ & $0.091( \pm 0.007)$ & $0.139( \pm 0.001)$ & 10 & 11.9 & 10.6 & 41 & 22 \\
\hline $0.4 / 18$ & $0.047( \pm 0.000)$ & $0.137( \pm 0.002)$ & 11 & 11.3 & 5.9 & 62 & Stunt \\
\hline $0.2 / 18$ & $0.188( \pm 0.001)$ & $0.137( \pm 0.001)$ & 12 & 16.4 & 15.1 & 38 & 46 \\
\hline $0.05 / 24$ & $0.046( \pm 0.003)$ & $0.032( \pm 0.015)$ & 116 & 14.9 & 36.5 & 35 & 9 \\
\hline Treatments mean & 0.063 & 0.090 & - & 15.4 & 15.9 & 47.94 & 50.67 \\
\hline Control & $0.106( \pm 0.010)$ & $0.111( \pm 0.045)$ & - & $14.55( \pm 2.53)$ & $30.46( \pm 19.97)$ & $46.7( \pm 2.517)$ & $23.0( \pm 7.024)$ \\
\hline \multicolumn{8}{|l|}{ Amman } \\
\hline $0.1 / 18$ & $0.039( \pm 0.027)$ & $0.192( \pm 0.092)$ & 4 & 14.1 & 10.5 & 41 & 24 \\
\hline $0.2 / 24$ & $0.076( \pm 0.008)$ & $0.178( \pm 0.069)$ & 5 & 16.9 & 46.9 & 67 & 35 \\
\hline $0.4 / 24$ & $0.106( \pm 0.003)$ & $0.171( \pm 0.047)$ & 6 & 19.9 & 5.8 & 44 & Stunt \\
\hline $0.1 / 24$ & $0.048( \pm 0.000)$ & $0.158( \pm 0.007)$ & 7 & 23.2 & 86.6 & 32 & 22 \\
\hline $0.4 / 24$ & $0.027( \pm 0.002)$ & $0.156( \pm 0.110)$ & 8 & 23.8 & 18.1 & 49 & 28 \\
\hline $0.2 / 18$ & $0.091( \pm 0.001)$ & $0.153( \pm 0.082)$ & 9 & 13.9 & 3.3 & 24 & stunt \\
\hline $0.1 / 18$ & $0.042( \pm 0.003)$ & $0.023( \pm 0.017)$ & 120 & 20.8 & 22.7 & 45 & 27 \\
\hline Treatments mean & 0.063 & 0.083 & - & 20.1 & 26.3 & 41.91 & 29.70 \\
\hline Control & $0.053( \pm 0.140)$ & $0.092( \pm 0.011)$ & - & $15.48( \pm 2.04)$ & $11.20( \pm 6.39)$ & $44( \pm 8.66)$ & $28.67( \pm 3.51)$ \\
\hline
\end{tabular}

Table 4: Morphological characteristics of H. triquetrifolium form Ramtha and Amman populations.

\begin{tabular}{|c|c|c|c|c|c|c|c|}
\hline \multirow[b]{2}{*}{ Treatment } & \multicolumn{2}{|l|}{$\begin{array}{l}\text { Plant height } \\
(\mathrm{cm})\end{array}$} & \multicolumn{2}{|l|}{$\begin{array}{l}\text { Leaf /plant } \\
(\%)\end{array}$} & \multirow{2}{*}{$\begin{array}{l}\text { Leaf shape } \\
1^{\text {st }} \text { Season } \\
\end{array}$} & \multicolumn{2}{|c|}{$\begin{array}{l}\text { Dark nodules /leaf } \\
\text { (No.) }\end{array}$} \\
\hline & $1^{\text {st }}$ Season & $2^{\text {nd }}$ Season & $1^{\text {st }}$ Season & $2^{\text {nd }}$ Season & & $1^{\text {st }}$ Season & $2^{\text {nd }}$ Season \\
\hline \multicolumn{8}{|l|}{ Colchicine $(\% / \mathrm{hrs})$} \\
\hline \multicolumn{8}{|l|}{ Ramtha } \\
\hline $0.3 / 30$ & 25 & 30 & 45.73 & 63.83 & ovoid & 65 & 26 \\
\hline $0.2 / 30$ & 37 & 8 & 31.96 & Stunt & linear & 99 & stunt \\
\hline $0.1 / 30$ & 27 & 5 & 42.95 & Stunt & linear & 61 & stunt \\
\hline $0.2 / 24$ & 22 & 35 & 48.2 & 59.86 & linear & 39 & 20 \\
\hline $0.4 / 18$ & 24 & 8 & 56.16 & Stunt & ovoid & 47 & stunt \\
\hline $0.2 / 18$ & 23 & 60 & 43.3 & 41.03 & linear & 62 & 14 \\
\hline $0.05 / 24$ & 36 & 48 & 73.13 & 96.92 & linear & 48 & 22 \\
\hline Treatments mean & 28.22 & 38.20 & 47.94 & 50.67 & - & 42.19 & 14.13 \\
\hline Control & $21.7( \pm 4.51)$ & $54.0( \pm 9.07)$ & $46.7( \pm 9.22)$ & $50.6( \pm 11.73)$ & Varied & $51.4( \pm 7.10)$ & $20.3( \pm 19.90)$ \\
\hline \multicolumn{8}{|l|}{ Amman } \\
\hline $0.1 / 18$ & 30 & 25 & 42.88 & 53.72 & linear & 41 & 19 \\
\hline $0.2 / 24$ & 53 & 38 & 29.86 & 38.04 & linear & 27 & 15 \\
\hline $0.4 / 24$ & 28 & 8 & 37.2 & Stunt & ovoid & 38 & stunt \\
\hline $0.1 / 24$ & \begin{tabular}{|l|}
40 \\
\end{tabular} & 45 & 47.42 & 50.81 & linear & 31 & 9 \\
\hline $0.4 / 24$ & 44 & 25 & 50.2 & 53.85 & elliptic & 33 & 15 \\
\hline $0.2 / 18$ & 24 & 7 & 38.07 & Stunt & elliptic & 48 & stunt \\
\hline $0.1 / 18$ & 34 & 30 & 27.83 & 11.44 & linear & 36 & 15 \\
\hline Treatments mean & 38.52 & 34.18 & 42.64 & 49.13 & - & 34.81 & 13.45 \\
\hline Control & $23.7( \pm 6.51)$ & $34.0( \pm 6.18)$ & $48.4( \pm 4.99)$ & $48.6( \pm 17.24)$ & varied & $46.9( \pm 6.70)$ & $12.9( \pm 7.10)$ \\
\hline
\end{tabular}

Genetic similarity between the six highest hypericin producing with the lowest producing and untreated controls for Ramtha and Amman populations are presented in the AFLP dendrograms (figure 1). Nei genetic distance $(\mathrm{Da})$ revealed the deviation of treated plants from their untreated controls in Ramtha $(\mathrm{Da}=)$ 0.16 and Airport $(\mathrm{Da}=0.18)$ wild populations. Genetic makeup of the compared plants separated them into 4 and 3 different groups in Ramtha and Amman wild populations, respectively. In the two dendograms the untreated plants from the two wild populations were grouped closely together and solely within their subgroups, whereas the colchicine treated plants dispersed on the other clusters. Certain treated plants were widely distanced in their genetics and grouped solely; these were the lowest hypericin producing plant (rank-116) from Ramtha population and the highest dry weight and total hypericin producing plant (rank-7) from Amman population.

These results are reflecting the genetic modifications and diversity within the treated new materials as well as with the untreated controls. H. triquetrifolium plant size enlarged, hypericin content and total produced hypericin improved. Owing to the increased demand on hypericin from Hypericum species, the processing industry requires uniform raw material of high quantity and quality, product characteristics that can be obtained only by cultivation [25]. The newly developed plants will encourage the commercial production of hypericin form $\mathrm{H}$. triquetrifolium. Tissue culturing of the high hypericin producing plants will ensure the homogeneity in commercial field establishments and seed production and their generated progenies will be evaluated. 


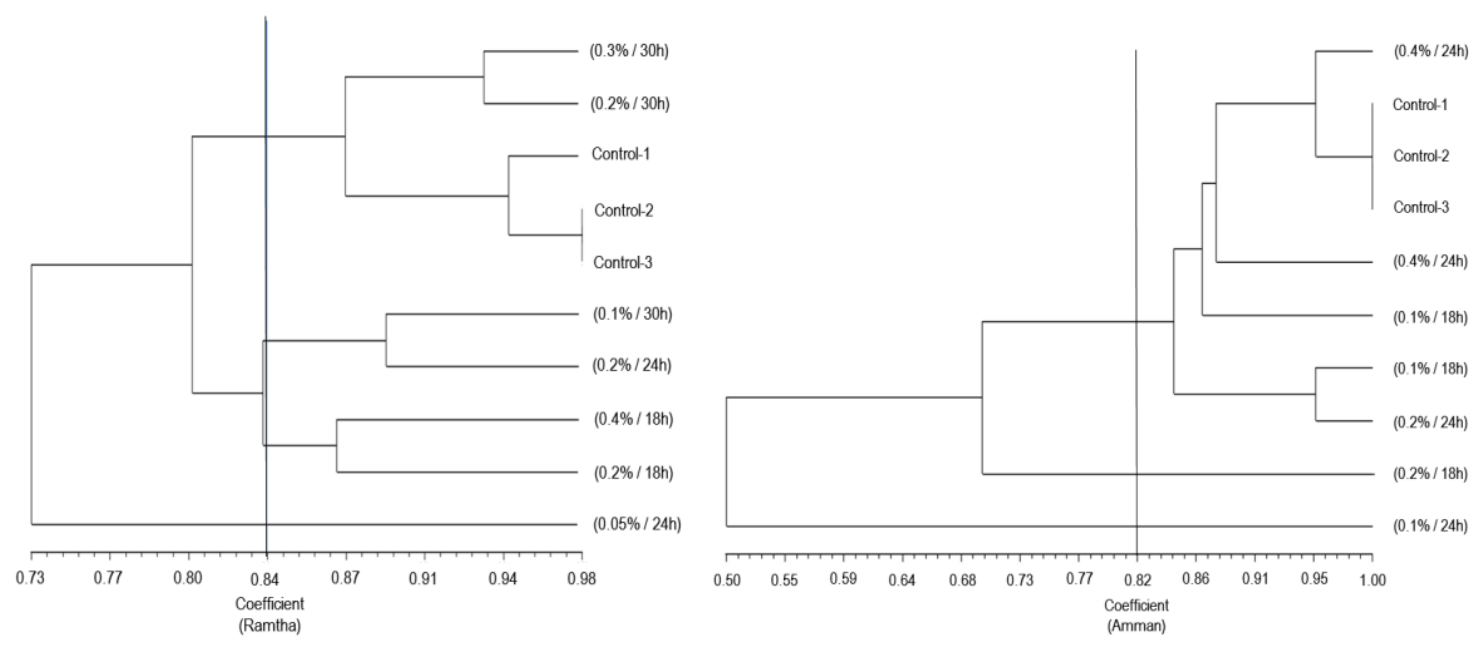

Fig. 1: Dendrograms of genetic similarity for the colchicine treated $H$. triquetrifolium populations using six AFLP primers.

\section{ACKNOWLEDGMENT}

The authors want to thank Prof. Ayied Al-Abdalat and Shireen Qassrawee at Hamdi Mango Center for Scientific Research-(HMCSR), University of Jordan for the technical help with the AFLP experiments. Thanks extended to Musa Swalaha for his follow up for the field and lab works. This research was kindly supported by Jordan Scientific Research Fund (JSRF).

\section{REFERENCES}

[1] Nürk, N and F, Blattner, 2010. Cladistic analysis of morphological characters in Hypericum (Hypericaceae). Taxon, 59(5): 1495-1507

[2] Crockett, S, and N, Robson, 2011. Taxonomy and chemotaxonomy of the genus Hypericum. Medicinal and Aromatic Plant Science and Biotechnology, 5 (1): $1-13$

[3] Robson, N, 1996. Studies in the genus Hypericum L. (Guttiferae) 6. Sections 20. Myriandra to28.Elodes. Bull. Br. Museum Nat. Hist, 26(2):75-217

[4] Nahrsted, A., and V, Butterweck, 1997. Biologically active end other chemical constituents of the herb of Hypericum perforatum L. Pharmacopsychiatry, 30: $129-134$

[5] Messina, B A, 2006. Herbal supplements: Facts and myths-talking to your patients about herbal supplements. Journal of Peri Anesthesia Nursing, 21: 268278

[6] Sanchez-Mateo, C, B, Prado, and R. Rabanal, 2002. Antidepressant effects of the methanol extract of several Hypericum species from the Canary Islands. Journal of Ethnopharmacology, 79: 119-127

[7] Cirak, C, J, Radusiene, H, Aksoy, R, Mackinaite, Z, Stanius, N, Camas, and M, Odabas, 2014. Differential Phenolic Accumulation in Two Hypericum Species in Response to Inoculation with Diploceras hypericinum and Pseudomonas putida. Plant Protect. Sci., 50(3): 119-128

[8] Baytop, T, 1999. Therapy with medicinal plants in Turkey. Istanbul University Press, Istanbul: 66-167

[9] Ozturk, B, S, Apaydin, E, Goldeli, I, Ince, and U, Zeybek, 2002. Hypericum triquetrifolium Turra extract exhibits antiinflammatory activity in the rat. Journal of Ethnopharmacology, 80: 207-209

[10] Pistelli, L, A, Bertoli, I, Morelli, F, Menichini, R, Musmanno, T, di Maggio, and G, Coratza, 2005. Chemical and antibacterial evaluation of Hypericum triquetrifolium Turra. Phytotherapy Research, 19: 787-791

[11] Fraternalea, D, A, Bertoli, L, Giamperi, A, Bucchini, D, Ricci, F, Menichini, E, Trinciarelli, and L, Pistelli, 2006. Antifungal evaluation of Hypericum triquetrifolium polar extracts against Fusarium spp. Natural Product Communications, 1: 1117-1122

[12] Conforti, F, M, Loizzo, A, Statti, and F, Menichini, 2007. Cytotoxic activity of antioxidant constituents from Hypericum triquetrifolium Tura. Natural Product Research, 21: 42-46

[13] Kizil, G, M, Kizil, M, Yavuz, S, Emen, and F, Hakimo 'glu, 2008. Antioxidant Activities of Ethanol Extracts of Hypericum triquetrifolium and Hypericum scabroides. Pharmaceutical Biology, 46(4): 231-242

[14] Cirak, C, J, Radusiene, V, Januli, L, Ivanauskas, N, Camas, and A, Ayan, 2011. Phenolic constituents of Hypericum triquetrifolium Turra (Guttiferae) growing in Turkey: variation among populations and plant parts. Turk. J. Biol., 35: 449-456

[15] Alali, F, K, Tawaha, and T, Al-Eleimat, 2004. Determination of hypericin content in Hypericum triquetrifolium Turra (Hypericaceae) growing wild in Jordan. Nat. Prod. Res., 18(2):147-151

[16] Gastpar, M, and K, Zeller, 2005. Hypericum-extrakt STW3 und sertralin zur ehandlung der mittelschweren depression. Psychopharmakotherapie, 12: 146153

[17] Schulz, V, 2002. Clinical trials with Hypericum extracts in patients with depression results, comparisons, conclusions for therapy with antidepressant drugs Phytomedicine, 9 (5): 468-474

[18] Crockett, S, B, Schaneberg, and I, Khan, 2005. Phytochemical profiling of new and old world Hypericum (St. John 's Wort) species. Phytochemical Analysis, 16: 479-485

[19] Bertoli, A, F, Menichini, M, Mazzetti, G, Spinelli, and I, Morelli, 2003. Volatile constituents of the leaves and flowers of Hypericum triquetrifolium Turra. Flavour and Fragrance Journal, 18(2):91-94

[20] Al-Rifaee, M, N, Haddad, and T, Aburjai, 2010. Domestication of wild Hypericum triquetrifolium populations under semi-arid environment of Jordan: Cultivation potential and breeding perspectives. Journal of Herbs, Spices and Medicinal Plants, 16 (1), 51-62

[21] Vos P, R, Hogers, M, Bleeker, M, Reijans, T, Van de Lee, M, Hornes, A, Frijters, J, Pot, J, Peleman, M, Kuiper, and M, Zabeau, 1995. AFLP: a new technique for DNA fingerprinting. Nucleic Acids Re., 23: 4407-4414

[22] Nei, M, 1972. Genetic distance between populations. American Naturalist, 106: 283-292

[23] Rohlf FJ, 1998. NYSYS-pc. Numerical taxonomy and Multivariate Analysis System, Version 2.02 Exeter Software, Setauket, NY

[24] Kwon, S, K, Cho, and H, Kim, 2013. A tetraploid induction in Hypericum patulum Thunberg by colchicine soaking treatment. Korean J. Plant Res., 26(2):284-288

[25] Lozykowska, K, and K, Kazmierczak, 2005. Evaluation of St. John's Wort (Hypericum perforatum L.) collection. Folia Horticult., 17(1):101-108. 